\title{
Two new species of the genus Protracheoniscus Verhoeff, 1917 (Isopoda: Oniscidea: Agnaridae) from the Lower Volga region
}

\author{
Ава новых вида рода Protracbeoniscus Verhoeff, 1917 \\ (Isopoda: Oniscidea: Agnaridae) из Нижкнего Поволжья
}

\author{
Konstantin B. Gongalsky \\ K.Б. Гонгальский
}

\begin{abstract}
A.N. Severtsov Institute of Ecology and Evolution of Russian Academy of Sciences, Moscow 119071, Russia. E-mail: gongalsky@gmail.com Институт проблем экологии и эволюции им. А.Н. Северцова РАН, Москва, 119071, Россия.
\end{abstract}

KEY WORDS: Isopoda, Oniscidea, Protracheoniscus, new species, woodlouse, Volga.

КЛЮЧЕВЫЕ СЛОВА: Isopoda, Oniscidea, Protracheoniscus, новый вид, мокрица, Волга.

ABSTRACT. Two new species of woodlice, Protracheoniscus halophilus sp.n. and P. spiridonovi sp.n. are described from Astrakhan Region and the Republic of Kalmykia, northeastern Pre-Caspian region, Russia. Diagnostic features of these species as well as affinities within the genus are provided and discussed.

How to cite this paper: Gongalsky K.B. 2021. Two new species of the genus Protracheoniscus Verhoeff, 1917 (Isopoda: Oniscidea: Agnaridae) from the Lower Volga region // Arthropoda Selecta. Vol.30. No.3. P.331-340. doi: 10.15298/arthsel. 30.3.06

РЕЗЮМЕ. Описаны два новых вида мокриц, Protracheoniscus halophilus sp.n. и P. spiridonovi sp.n., из Астраханской области и Республики Калмыкия, северо-восточная часть Прикаспийского региона, Россия. Представлены и обсуждены диагностические особенности новых видов, а также сродство в пределах рода.

\section{Introduction}

The highest diversity of terrestrial isopods in Russia is recorded in the eastern Mediterranean and in the Caucasus [Kuznetsova, Gongalsky, 2012], mostly dependent on temperature and soil moisture to complete their life cycle [Csonka et al., 2018]. Within the former USSR, these regions as well as the Central Asia are relatively well surveyed with many records of terrestrial isopods [Borutzky, 1945, 1957]. However, there are gaps with very few isopod records across this territory, such as in the Caspian region [Kuznetsova, Gongalsky, 2012; Eshaghi et al., 2015; Kashani, Hamidnia, 2016]. The Lower Volga River basin (Pre-Caspian region) attracts attention due to a unique position in Europe with natural steppes, and sometimes, with semi-deserts. During studies of soil fauna in the Lower Volga region, a number of isopod species were recorded. Some of them were new species [Gongalsky, 2017; Gongalsky et al., 2018]. The present work aims at describing two more new species of the genus Protracheoniscus Verhoeff, 1917 of the family Agnaridae Schmidt, 2003.

\section{Materials and methods}

The sampling was done by the author in the Lower Volga region in 2019. Woodlice were collected by hand and fixed in $96 \%$ ethanol. Processing and dissections were done by using a Leica MZ8 binocular microscope. Micro preparations of diagnostic body appendages were done in euparal (Carl Roth $\mathrm{GmbH})$. Line drawings were executed with the help of an Olympus BX41 microscope supplied with an Olympus U-DA camera lucida.

Some specimens were lyophilized with the help of a Hitachi Critical Point Dryer HCP-1 (Hitachi Ltd., Japan), attached to stubs, coated with carbon in a Q150R ES Plus (Quorum Technologies Ltd., UK), and studied under a Tescan Mira 3 LMH (Tescan, Czech Republic) scanning electron microscope.

Terminology used in the species description is mainly based on Vandel [1960].

The material is deposited in the collection of the Zoological Museum of Moscow University, Russia (ZMMU), and partly retained in the private collection of the author (A.N. Severtsov Institute of Ecology and Evolution of Russian Academy of Sciences, Moscow, Russia), as indicated below.

Taxonomic part

Class Malacostraca Latreille, 1802 Order Isopoda Latreille, 1817

Family Agnaridae Schmidt, 2003

Genus Protracheoniscus Verhoeff, 1917

Protracheoniscus halophilus sp.n. Figs 1-5.

HOLOTYPE, OT (ZMMU Mc-1427), Russia, Astrakhan Region, shore of Menkerke-Khag Lake, 46.28N, 47.16E, leg. K. Gongalsky, 1.05. 2019. 

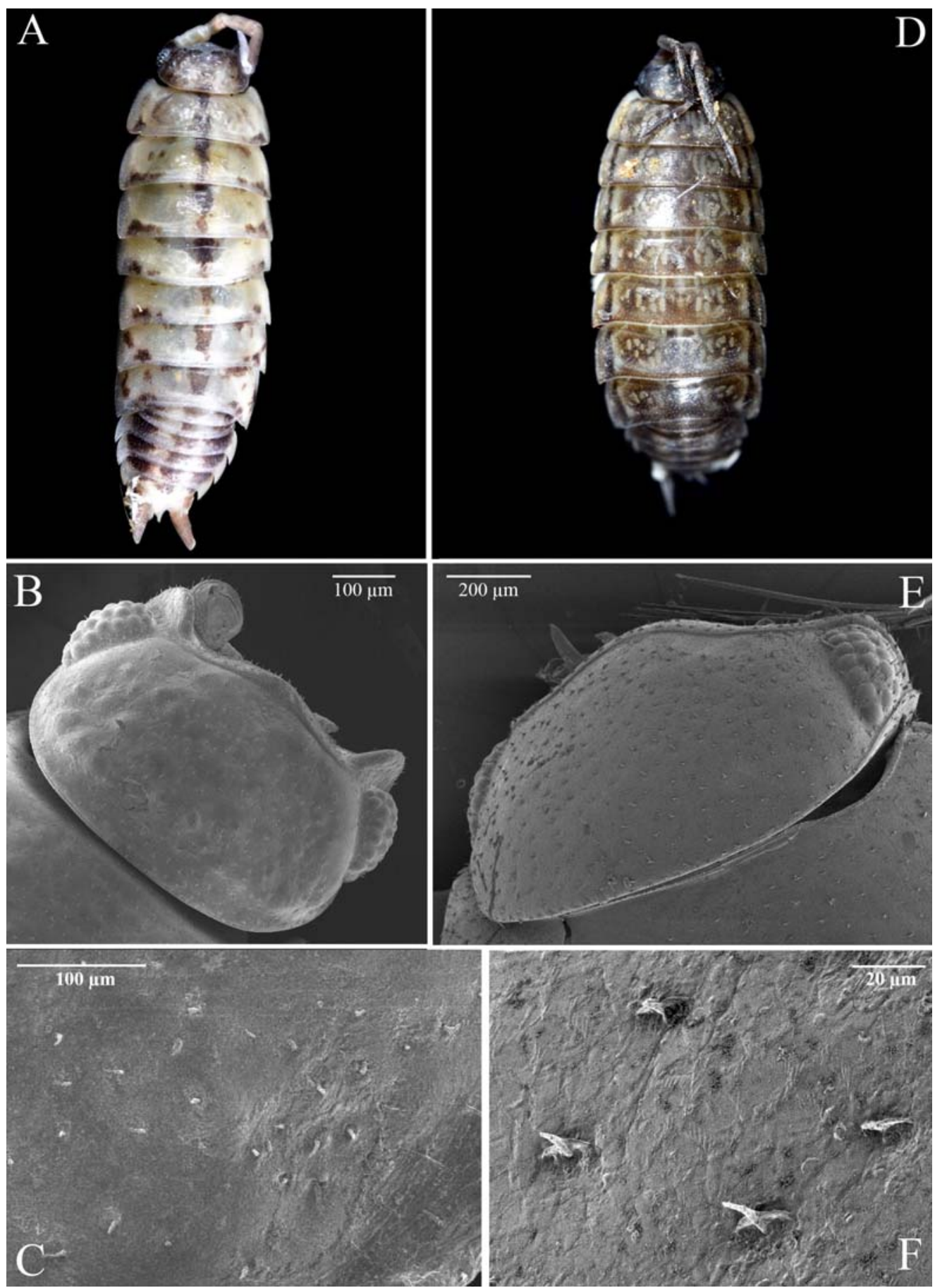

Fig. 1. Protracheoniscus halophilus sp.n., paratype (male): A - dorsal view; B - head; C - dorsal setae. Protracheoniscus spiridonovi sp.n., paratype (male): D - dorsal view; E - head; F — dorsal setae. Photographs by F. Byzov, not taken to scale.

Pис. 1. Protracheoniscus halophilus sp.n., паратип (самец): А — габитус сверху; В — голова; С — дорсальная сета. Protracheoniscus spiridonovi sp.n., паратип (самец): D - габитус сверху; Е - голова; F — дорсальная сета. Фотографии Ф. Бызова, сняты без масштаба.

PARATYPES, $3 \sigma^{\top} \sigma^{\top}, 3+0$ (ZMMU Mc-1428), $3 \sigma^{\top} \sigma^{\top}, 3+9$ (private collection of K. Gongalsky), same date, location and collector as the holotype.

DIAGNOSIS. The species of Protracheoniscus is characterized by the antennal flagellum with proximal article longer than the distal one; maxillula outer endite bearing 6 teeth; male exopod of pleopod 1 almost round.
DESCRIPTION. Somatic characters. Maximum body length: male $12.0 \mathrm{~mm}$; female $12.5 \mathrm{~mm}$. Holotype body length $11.6 \mathrm{~mm}$. Body colored in light grey-brown with white areas reaching in some individuals up to $80 \%$ of body surface. Pereonites 2-7 epimera bearing white or yellow spots on posterior portion (Fig. 1A). Body elongated; pleo- 

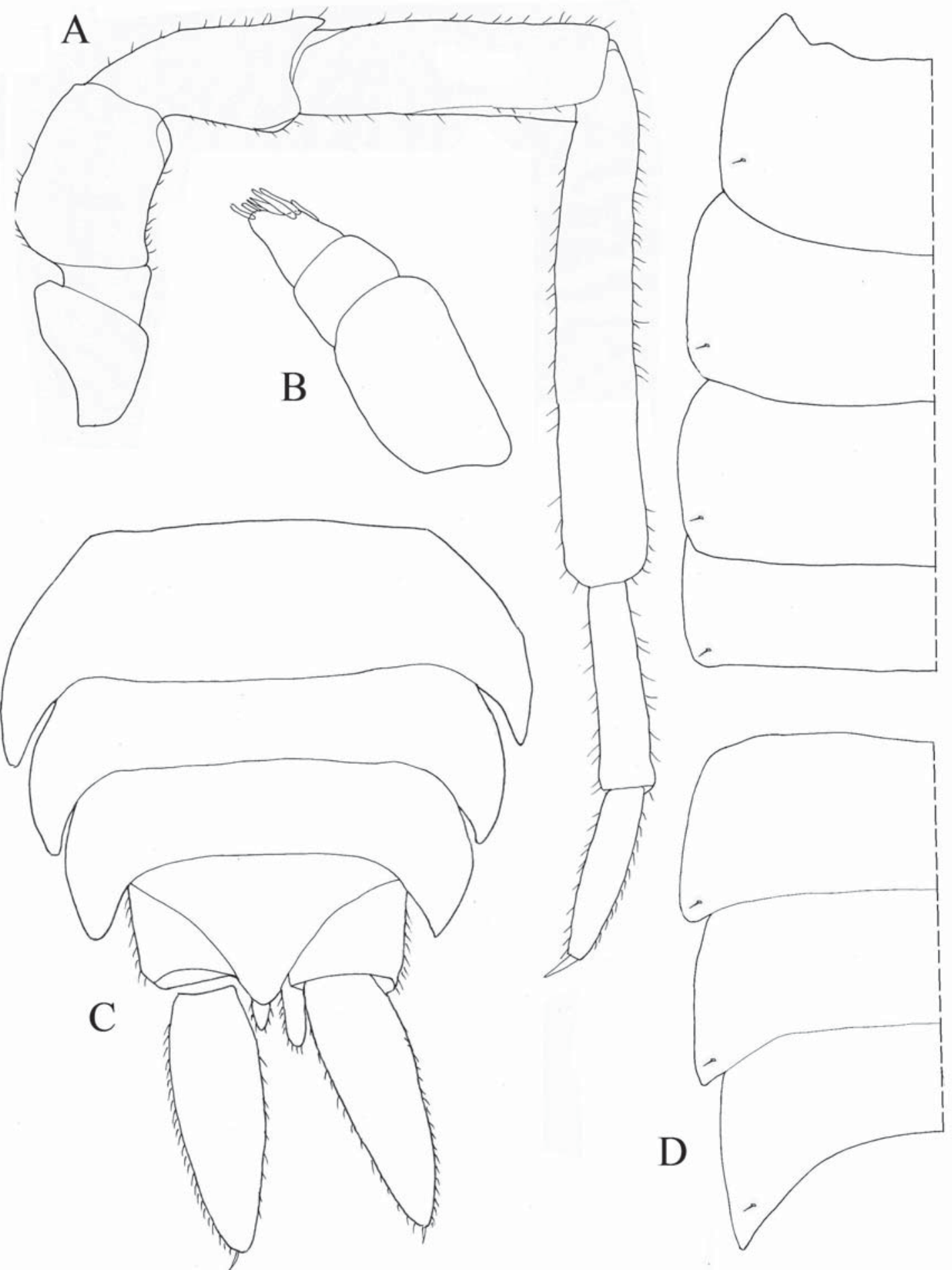

Fig. 2. Protracheoniscus halophilus sp.n., male (paratype): A — antenna; B — antennula; C — pleon, telson and uropodes; D pereon edge.

Рис. 2. Protracheoniscus halophilus sp.n., самец (паратип): А — антенна; В - антеннула; C — плеон, тельсон и уроподы; D край переиона.

nites 3-5 not continuous with outline of pereonite 7 . Dorsal surface of tergites smooth; covered with scattered sharp triangular dorsal setae (Fig. 1C). Noduli laterales inserted near posterior margins (Fig. 2D). Cephalic lobes poorly developed; distal edge of median lobe rounded (Fig. 1B). Telson triangular; distal part elongated and distal corner forming triangle (Fig. 2C). Uropods (Fig. 2C) coloured as dorsal surface of body. 

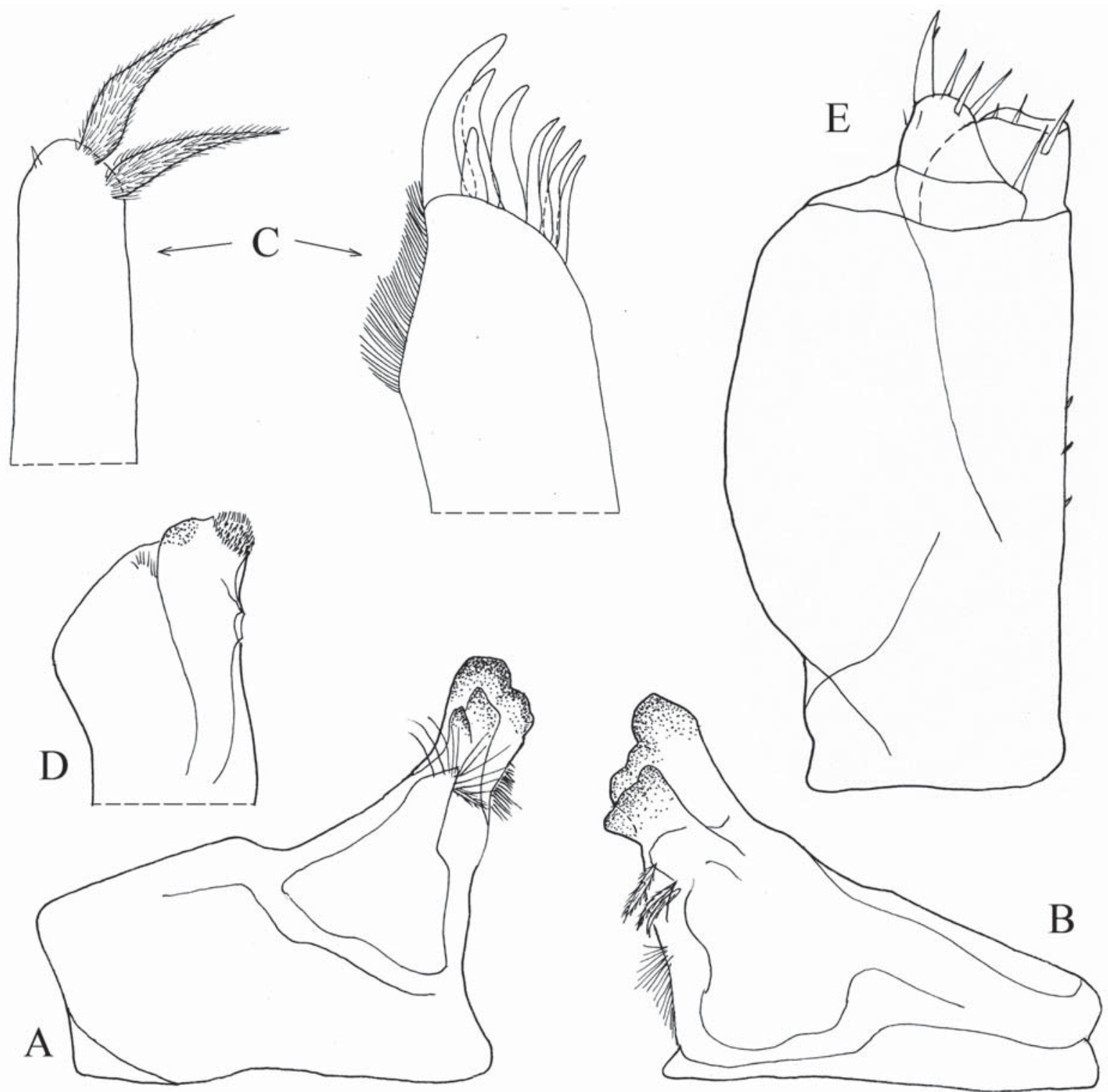

Fig. 3. Protracheoniscus halophilus sp.n., male (paratype): A — left mandible; B — right mandible; C - maxillula; D - maxilla; E maxilliped.

Pис. 3. Protracheoniscus halophilus sp.n., самец (паратип): А — левая мандибула; В — правая мандибула; C — максиллула; D максилла; Е - максиллипед.

Appendages. Uropod exopods elongated with widest part on $1 / 3$ proximal distance. Antennula with three articles (Fig. 2B); first article wide and relatively long; second article 2.5 times shorter than first; third article almost as long as second and narrow, bearing about 7 aesthetascs. Antenna medium long, reaching pereonite 3 when extended posteriorly; flagellum with 2 articles, proximal one slightly longer than distal one (Fig. 2A).

Left mandible (Fig. 3A) with molar process with 2 penicils and lacinia mobilis with straight edge; basal to lacinia hairy lobe with row of ca. 10 setae. Right mandible (Fig. 3B) smaller than left mandible consisting of molar process with 3 teeth and lacinia mobilis with 2 teeth and hairy lobe with row of ca. 10 penicils. Maxillula (Fig. 3C): medial corner of inner endite with 2 strong hirsute setae. Apical edge of outer endite bearing 6 spines divided into two groups, 3 in each. Tip of endite covered with dense brush of setae. Maxilla (Fig. 3D) with bilobate edge, medial half of apical edge of inner lobe with dense brush of short hairs. Inner lobe rounded and covered with thick setae; outer lobe rounded, wider than inner lobe and covered with thin setae. Inner margin with subapical tubercle. Maxilliped (Fig. 3E) with outer corner of endite with 2 acute tips and large spine near the inner corner.

Pereopods (Fig. 4A-C). Carpus 1 the widest on distal half unlike carpi of legs 6 and 7 which taper to the distal part. Spines on distal parts of carpus 1 with split tips.

Male: All exopods (Fig. 5A, C, E-G) on lateral margin with pleopodal lungs. Exopod of pleopod 1 (Fig. 5A) almost rounded and bears seven setae at apex, inner margin slightly 


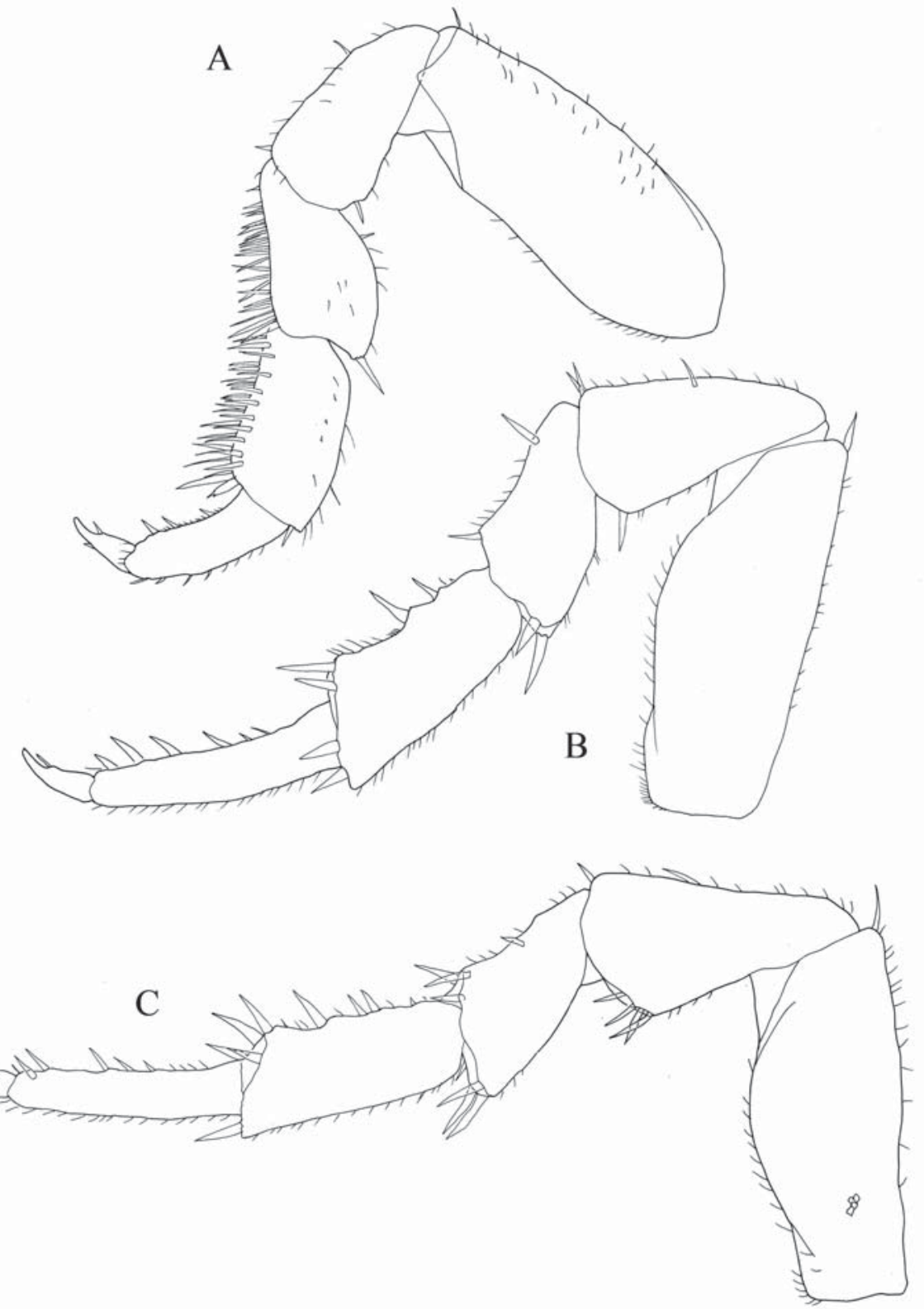

Fig. 4. Protracheoniscus halophilus sp.n., male (paratype): A - pereopod 1; B - pereopod 6; C - pereopod 7.

Рис. 4. Protracheoniscus halophilus sp.n., самец (паратип): А - переопод 1; В - переопод 6; С - переопод 7.

concave. Endopod of pleopod 1 (Fig. 5B) with split distal part: sharp triangular tubercle not inclined laterally bearing row of spines. Pleopod 2: exopod triangular with slightly concave outer margin bearing ca. 10 setae (Fig. 5C); endopod much longer than exopod, distal portion narrow (Fig. 5D). Pleopods 3-5: exopods (Fig. 5E-G) trapezoidal, slightly decreasing in size from 3 to 5 .

REMARKS. The species is assigned to the genus Protracheoniscus by having 5 pairs of pleopodal lungs, flagellum of antennae II consisting of two articles, poorly developed head median lobes [Schmölzer, 1965]. This species is the closest to $P$. politus (C. Koch, 1841) and P. pokarzhevskii Gongalsky et Turbanov, 2018 due to a similar shape of body parts. However, these two species differ in the following: (1) male exopod of pleopod 1 is almost rounded which is sharp- er in P. politus and P. pokarzhevskii; (2) maxillula outer endite bears 6 spines unlike $P$. politus and $P$. pokarzhevskii with 8 spines; (3) $P$. halophilus sp.n. is larger and brighter; (4) this is a halophilic species not found elsewhere outside shores of salted lakes.

DISTRIBUTION AND ECOLOGY. The species known from the type locality so far in the Lower Volga region. The specimens were collected on salted shores of lakes with a variety of halophilic vegetation (Salsola spp., Artemisia lerchiana, Agropyron fragile, and Anabasis aphylla) of the Astrakhan Region.

ETYMOLOGY. The new species name, halophilus (an-

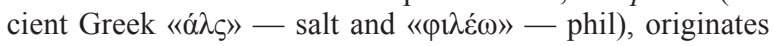
from saline environments around the lakes where this species was found. 


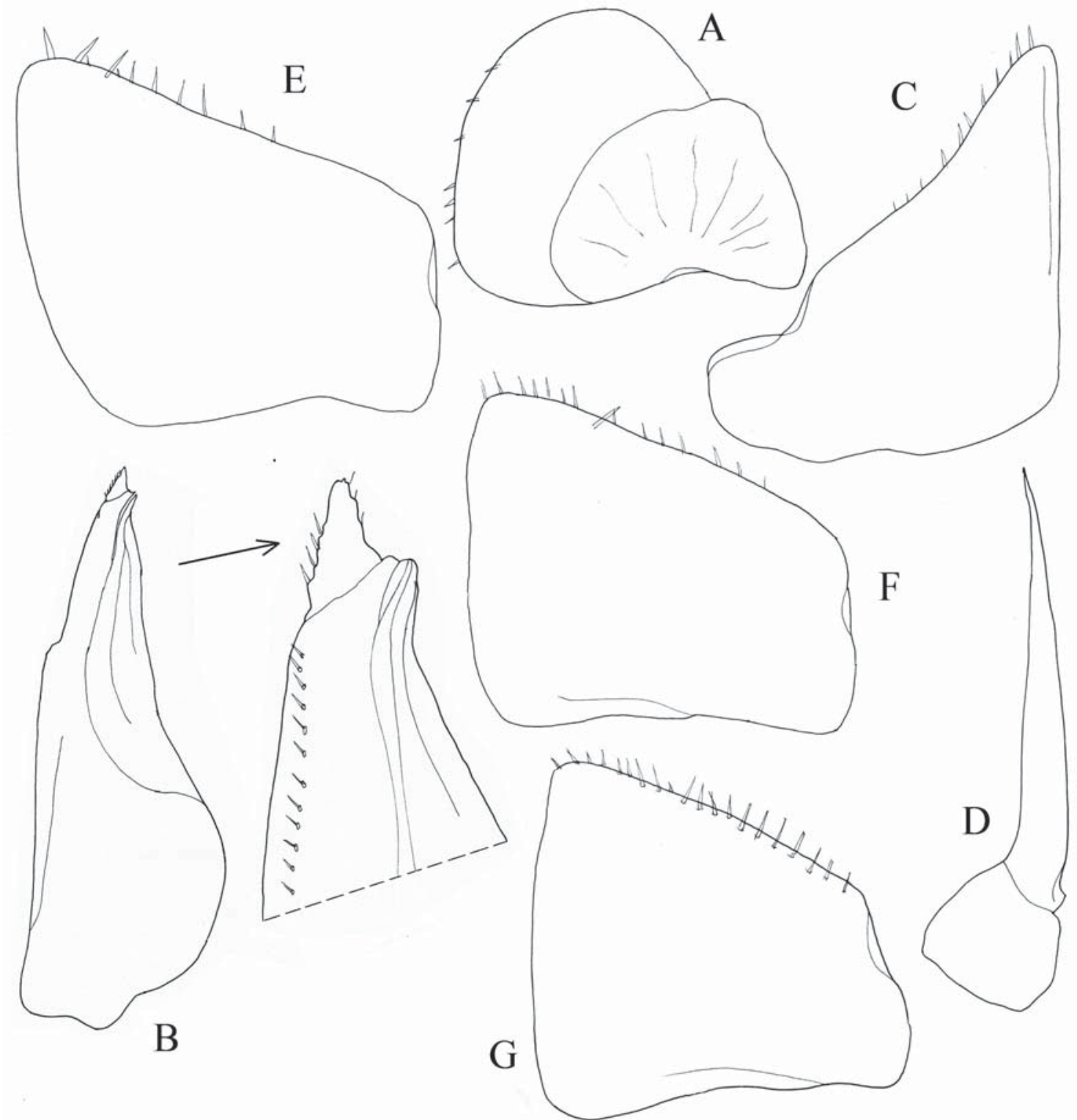

Fig. 5. Protracheoniscus halophilus sp.n., male (paratype): A - exopod of pleopod 1; B - endopod of pleopod 1; C - exopod of pleopod 2; D - endopod of pleopod 2; E - exopod of pleopod 3; F - exopod of pleopod 4; G - exopod of pleopod 5.

Рис. 5. Protracheoniscus halophilus sp.n., самец (паратип): А - экзопод плеопода 1; В - эндопод плеопода 2; С - экзопод плеопода 2; D - эндопод плеопода 2; Е - экзопод плеопода 3; F — экзопод плеопода 4; G — экзопод плеопода 5.

\section{Protracheoniscus spiridonovi sp.n.}

Figs 1, 6-9.

HOLOTYPE, o (ZMMU Mc-1429), Russia, Republic of Kalmykia, close to Idzhil, 47.42N 45.54 E, leg. K. Gongalsky, 2.05.2019.

PARATYPES, $2 \sigma^{\top} \sigma^{\top} 2+0$ (ZMMU Mc-1430), $2 \sigma^{\top} \sigma^{\top} 2+0$ (private collection of K. Gongalsky), same date, location and collector as the holotype.

DIAGNOSIS. The species of Protracheoniscus is characterized by the antennal flagellum with the articles of a ratio close to $1: 1$; male exopod of pleopod 1 almost rounded with concave apex; and distinct bump on merus pereopod 7 .

DESCRIPTION. Somatic characters. Maximum body length: male $10.0 \mathrm{~mm}$; female $10.3 \mathrm{~mm}$. Holotype body length $8.8 \mathrm{~mm}$. Body colour grey-brown. Pereonites 2-7 epimera bearing white or yellow spots (Fig. 1D). Dorsal surface of tergites smooth, covered with scattered star-shaped sharp dorsal setae (Fig. 1F). Body relatively elongated; pleonites 3-5 outline not continuous with outline of pereionite 7 (Fig. 1D). Posterior edges of pereon epimerae straight (Fig. 6D). Noduli lateralis inserted near posterior margins (Fig. 6D). Cephalic lobes almost absent. Distal edge of the median lobe rounded (Fig. 1E). Telson with distal part elongated and distal corner forming triangle (Fig. 6C). Uropods (Fig. 6C) coloured as dorsal body surface.

Appendages. Uropod exopods elongated with widest part on $1 / 3$ proximal distance. Antennula with three articles (Fig. 7B); first article wide and relatively long; second article 2.5 times shorter than first; third article slightly longer than 


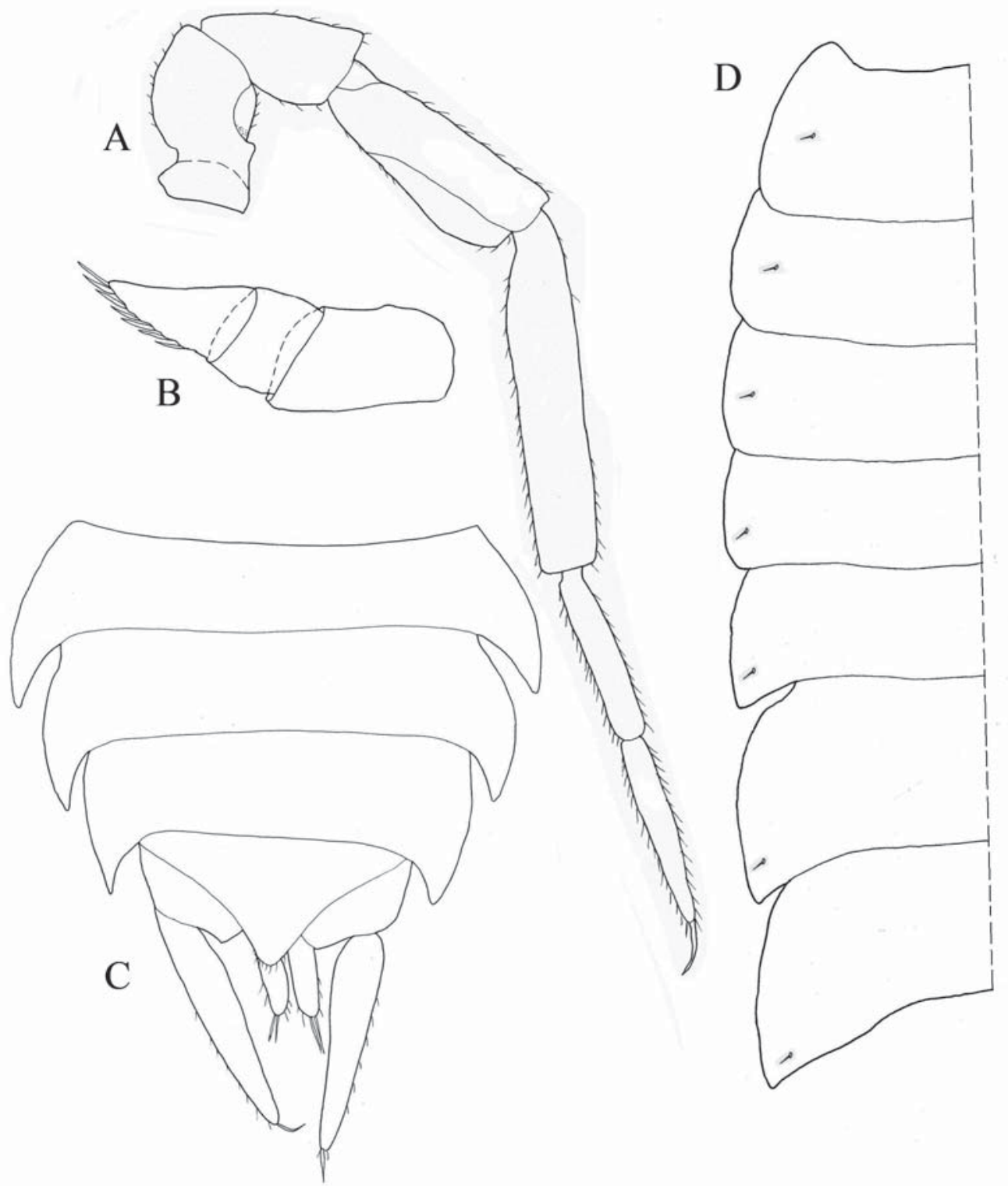

Fig. 6. Protracheoniscus spiridonovi sp.n., male (paratype): A — antenna; B — antennula; C — pleon, telson and uropodes; D pereon edge.

Рис. 6. Protracheoniscus spiridonovi sp.n., самец (паратип): А — антенна; В — антеннула; С — плеон, тельсон и уроподы; D край переиона.

second and narrow, bearing tuft of setae at apex. Antenna medium long, reaching pereonite 3 when extended posteriorly; flagellum with 2 articles of similar length (Fig. 6A).

Left mandible (Fig. 7A) with molar process with 2 penicils and lacinia mobilis with straight edge; basal to the lacinia is hairy lobe with row of ca. 10 setae. Right mandible (Fig. 7B) smaller than left mandible consisting of molar process with 3 teeth and lacinia mobilis with 2 teeth and hairy lobe with row of ca. 10 penicils. Maxillula (Fig. 7C): medial corner of inner endite with 2 strong hirsute setae. Apical edge of outer endite bearing 8 spines that divided into two groups, 4 in each. Smaller spines with split tips. Tip of endite covered with dense brush of setae. Maxilla (Fig. 7D) with bilobate edge, the medial half of the apical edge of both lobes with dense brush of short hairs. Inner margin with subapical tubercle. Maxilliped (Fig. 7E) with outer corner of endite with 2 acute tips and large spine near the inner corner.

Pereopods (Fig. 8A-C). Merus 7 with bump on $1 / 3$ proximal distance. Spines on distal parts of carpus 1 with split tips.

Male: All exopods (Fig. 9A, C, E-G) on lateral margin with pleopodal lungs. Exopod of pleopod 1 (Fig. 9A) almost rounded with concave tip and bears numerous setae at apex, inner margin slightly concave. Endopod of pleopod 1 (Fig. 9B) with distal part inclined laterally and bearing row of spines. Pleopod 2: exopod triangular with concave outer margin bearing numerous setae (Fig. 9C); endopod much longer than exopod, narrow (Fig. 9D). Pleopods 3-5: exopods (Fig. 9E-G) trapezoidal, slightly decreasing in size from 3 to 5 . 


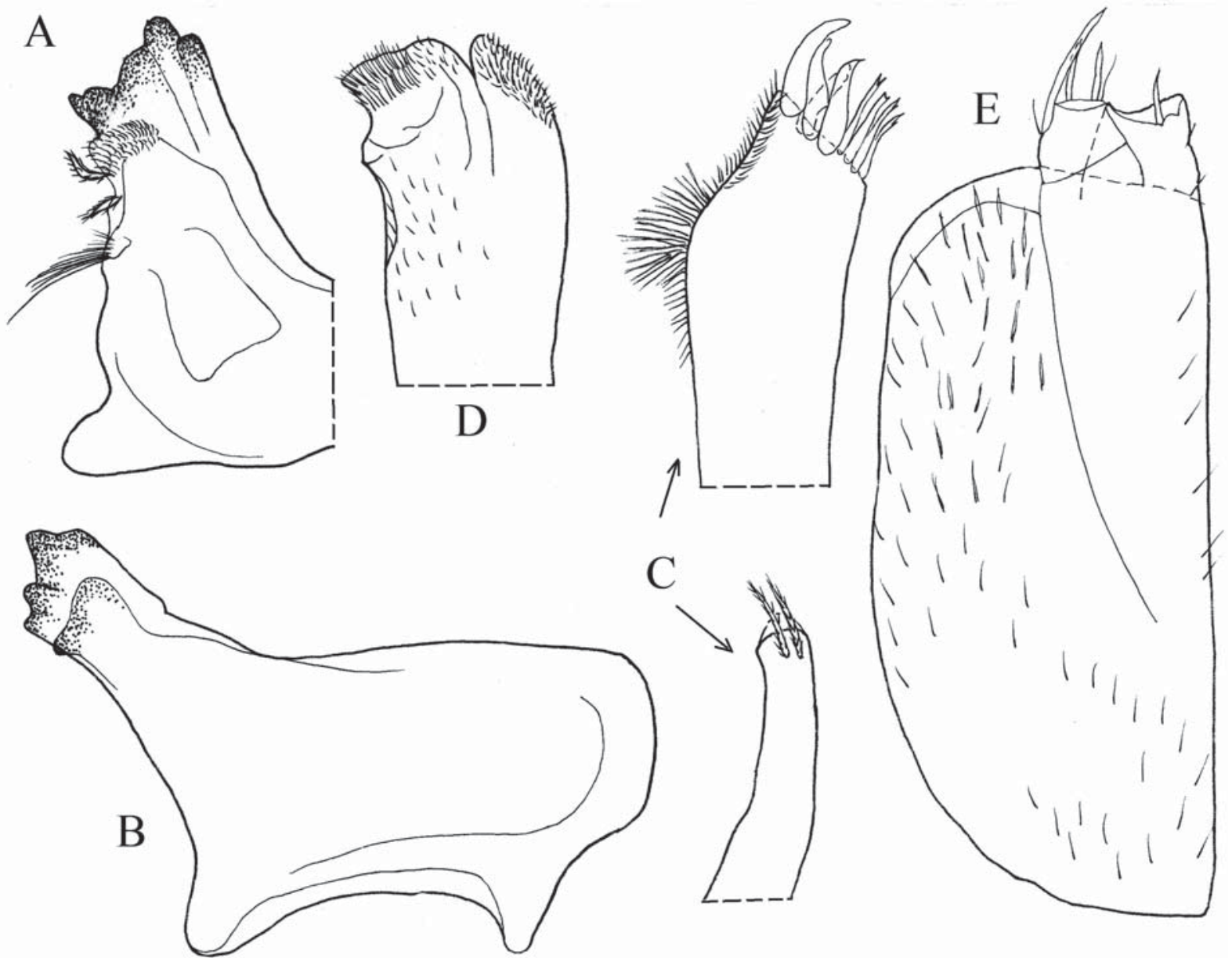

Fig. 7. Protracheoniscus spiridonovi sp.n., female (paratype): A — left mandible; B — right mandible; $\mathrm{C}$ - maxillula; D — maxilla; E - maxilliped.

Pис. 7. Protracheoniscus spiridonovi sp.n., самка (паратип): А — левая мандибула; В — правая мандибула; С — максиллула; D максилла; Е - максиллипед.

REMARKS. The species is assigned to the genus Protracheoniscus due to the same characters as the previous one. This species is the closest to P. kryszanovskii Borutzky, 1957 due to a similar shape of body. However, these two species differ in the following: (1) male endopod of pleopod 1 is inclined laterally in P. spiridonovi sp.n. unlike P. kryszanovskii; (2) noduli laterales on pereonites 3 and 5 are at the same distance from the edge as on other pereonites in $P$. spiridonovi sp.n. unlike $P$. kryszanovskii in which they are placed more centrally; (3) lateral head lobes in P. spiridonovi sp.n. are almost absent; (4) P. spiridonovi sp.n. has distinct bump on merus 7, while P. kryszanovskii on carpus 7.

DISTRIBUTION AND ECOLOGY. The species known from the type locality so far in the Lower Volga region. The specimens were found in the steppes with xerophytic vegetation (Artemisia austriaca, Festuca valesiaca, and Tanacetum achilleifolium) of Kalmykia.

ETYMOLOGY. The new species name, spiridonovi, originates from Dr. Vassily A. Spiridonov (1957-2020), a prominent Russian carcinologist.

Acknowledgements. The sampling and description were funded by the Russian Foundation for Basic Research, project
\#18-29-25067. I thank Daniil Korobushkin, Petr Garibian and Maxim Degtyarev for their help with sampling. All SEM works were carried out at the Joint Usage Center "Instrumental Methods in Ecology" at A.N. Severtsov Institute of Ecology and Evolution. I thank Anna Neretina for her help with producing SEM photographs, and Filipp Byzov for producing the habitus photographs.

\section{References}

Borutzky E.V. 1945. [Fauna of woodlice of Turkmenia and adjacent regions of Middle Asia] // Uchenye Zapiski Moskovskogo Gosudarstvennogo Universiteta. Vol.83. P.165-202 [in Russian]

Borutzky E.V. 1957. [Terrestrial isopods in the south-east of the European part of the USSR] // Zoologichesky Zhurnal. Vol.34. P.360-372 [in Russian, with English summary]

Csonka D., Halasy K., Buczko K., Hornung E. 2018. Morphological traits - desiccation resistance - habitat characteristics: a possible key for distribution in woodlice (Isopoda, Oniscidea) // Zookeys. Vol.801. P.481-499.

Eshaghi B., Kiabi B.H., Kashani G.M. 2015. The agnarid terrestrial isopods (Isopoda, Oniscidea, Agnaridae) of the province of 


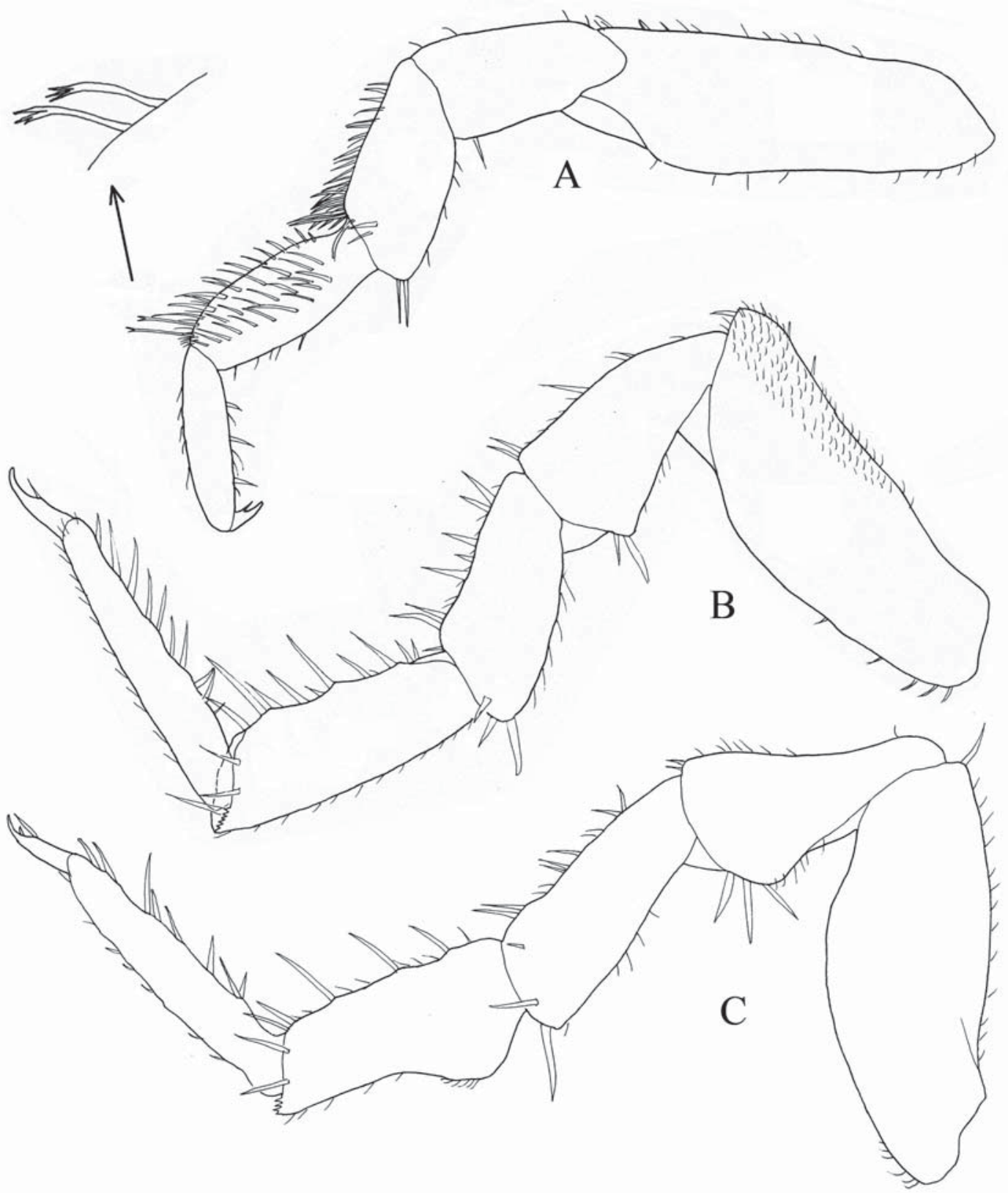

Fig. 8. Protracheoniscus spiridonovi sp.n., male (paratype): A — pereopod 1; B - pereopod 6; C - pereopod 7.

Рис. 8. Protracheoniscus spiridonovi sp.n., самец (паратип): А - переопод 1; В - переопод 6; С - переопод 7.

Qazvin, Iran, with a description of a new species // Zookeys. Vol.515. P.59-66.

Gongalsky K.B. 2017. The first record of the genus Desertoniscus Verhoeff, 1930 (Isopoda, Oniscidea, Agnaridae) from Europe, with the description of a new species // Zootaxa. Vol.4347. P.583-591.

Gongalsky K.B., Turbanov I.S., Medvedev D.A., Volkova J.S. 2018. Description of a new species of the genus Protracheoniscus Verhoeff, 1917 and redescription of Protracheoniscus kryszanovskii Borutzky, 1957 from the southeast of European Russia (Isopoda, Oniscidea, Agnaridae) // ZooKeys. Vol.801. P.189205.

Kashani G.M., Hamidnia S. 2016. Terrestrial isopods of the genus Protracheoniscus (Isopoda: Oniscidea) in northern Iran with a description of two new species // Turkish Journal of Zoology. Vol.40. P.345-351.

Kuznetsova D.M., Gongalsky K.B. 2012. Cartographic analysis of woodlice fauna of the former USSR // ZooKeys. Vol.176. P.111.

Schmölzer K. 1965 Bestimmungsbucher zur Bodenfauna Europas. Ordnung Isopoda (Landasseln). Lieferung 4 und 5. Berlin. 468 $\mathrm{S}$.

Vandel A. 1960. Isopodes terrestres (Première Partie) // Faune de France. Vol.64. Paris: Lechavalier. 416 pp.

Responsible editor I.N. Marin 


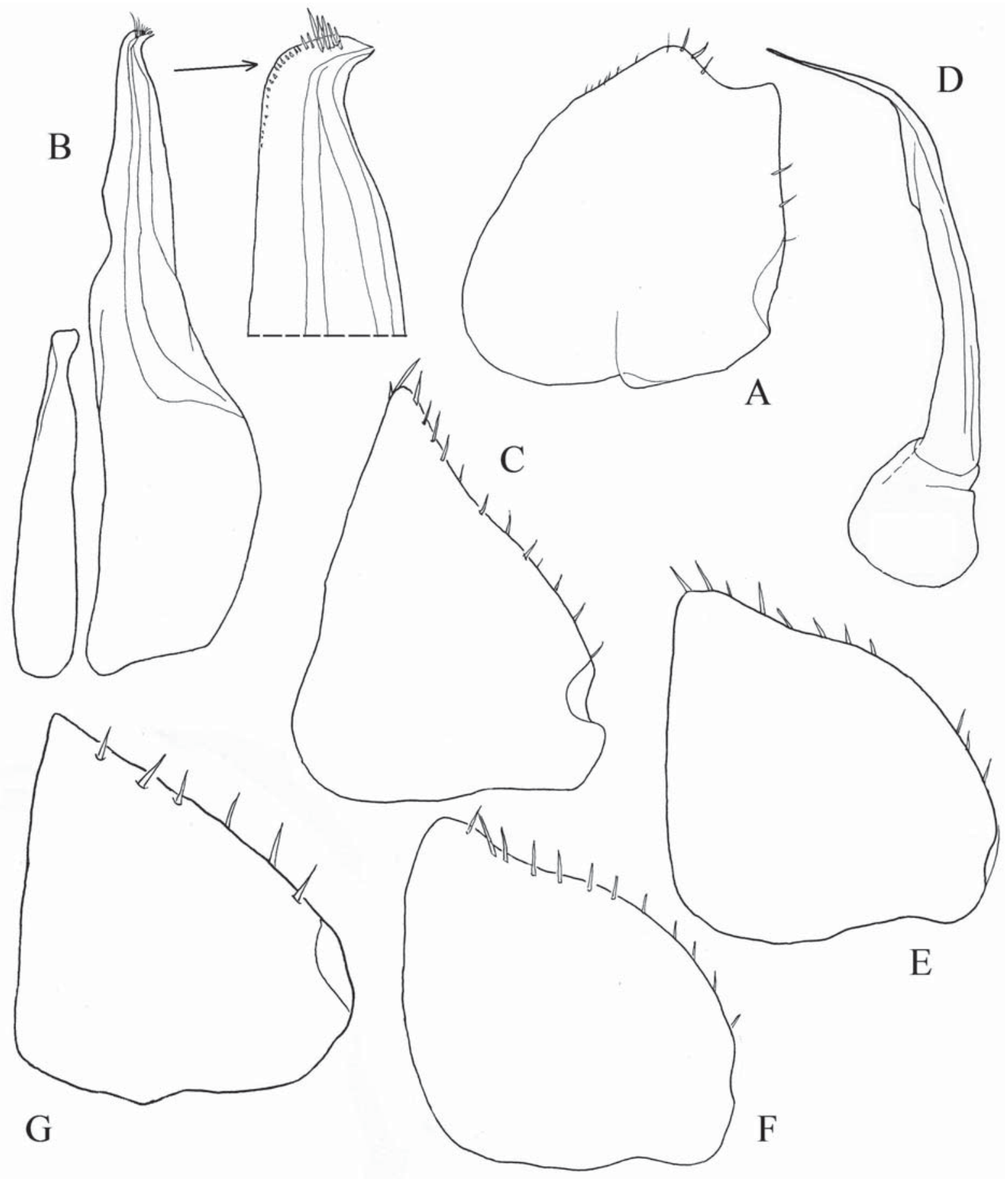

Fig. 9. Protracheoniscus spiridonovi sp.n., male (paratype): A — exopod of pleopod 1; B - endopod of pleopod 1 and genital papilla; C - exopod of pleopod 2; D - endopod of pleopod 2; E — exopod of pleopod 3; F — exopod of pleopod 4; G - exopod of pleopod 5.

Рис. 9. Protracheoniscus spiridonovi sp.n., самец (паратип): А - экзопод плеопода 1; В - эндопод плеопода 2 и генитальная папилла; $\mathrm{C}$ - экзопод плеопода $2 ; \mathrm{D}$ - эндопод плеопода 2 ; $\mathrm{E}$ - экзопод плеопода $3 ; \mathrm{F}$ - экзопод плеопода 4 ; $\mathrm{G}$ - экзопод плеопода 5. 